\title{
The Québec Sports Safety Board: a governmental agency dedicated to the prevention of sports and recreational injuries
}

One of the main activities of children and adolescents in the industrialized world is sports and recreation. ${ }^{1-4}$ However, these activities are responsible for a significant number of injuries severe enough to cause hospitalization or to require medical attendance. ${ }^{5-9}$ Considering the importance of sport and recreational injuries for most children and adolescents, it is useful to identify programs that have addressed this problem and to discover how they were created. Such initiatives could serve as models for other countries.

This paper describes an initiative taken by the province of Québec, Canada - the creation of the Québec Sports Safety Board (QSSB). The events leading to its creation, its mandate, as well as some of its legislative and regulatory powers, are described. Examples of interventions of particular interest for the safety of young participants are discussed in greater detail.

\section{The creation of the QSSB}

The QSSB was created in 1979 by an act of the National Assembly of the province of Québec. It is responsible for 'supervising personal safety and integrity in the practice of sports' ${ }^{10}$ The passage of the act followed years of public debate about the role of government in providing safety to sports participants. Until the 1960 s, most of that debate revolved around professional boxing. However, in 1964, a report from a government sponsored Task Force on Recreation, Physical Education, and Sports recommended that the government, in the name of common good, ensure that sports and recreation organizations, public or private, meet minimum safety standards for facilities, equipment, programs, and personnel. To that end, the task force recommended that government develop relevant legislation pertaining to the issue of operating permits and the certification of programs. ${ }^{11}$ The recommendations were not acted upon at that time, but the report raised important issues that were discussed frequently in the media over the following decade.

In 1972, and again in 1974, the government proposed the creation of a provincial boxing commission with no success. In 1976, a bill proposing the creation of a sports and recreation commission also failed to pass. From 1974 to 1979 , coroner inquests into the death of participants in recreational activities such as scuba diving, sky diving, ice hockey, and canoeing repeatedly noted the lack of legislation to ensure the safety of participants and called for governmental intervention. During the same years, violent events on and off the ice during junior hockey league games prompted the government to call for an inquiry into violence in ice hockey. The final report, published in 1977 , recommended the creation of an agency with quasijudiciary powers to enhance the safety of sports participants, namely a 'sports board' ${ }^{12}$

Exhaustive consultation of all the groups involved were held until 1979. Included were representatives from the 64 sports federations, the five universities offering physical education programs, and a sample of school boards and municipalities. In all, 89 meetings were held from which came the following consensus:

- Representatives from amateur sport were anxious to have a regulatory body that would enforce safety regulations;

- Efforts should be directed at informing all participants about the safety measures they can adopt to prevent sports injuries;

- Efforts should also be directed at improving the training of coaches and officials;

- Standards on sports facilities should be developed and enforced;

- The sports and recreation equipment consumer should be protected by the adoption of standards directed at manufacturers.

Following these consultations, the government adopted the Act Respecting Safety in Sport (1979) which created the QSSB.

\section{The mandate}

The board supervises the execution of the Act Respecting Safety in Sport and its regulations. For that purpose it is empowered to:

1. Gather, analyze, and disseminate information on sports safety;

2. Conduct, or cause others to conduct, research on sports safety;

3. Educate the public on safety in relation to the practice of sports;

4. Prepare safety training methods for persons who work in the sports field;

5. Give technical assistance to sports federations or unaffiliated sports bodies in preparing safety regulations;

6. Assist any person requesting advice on means to ensure sports safety. ${ }^{10}$

A full time president of the board is appointed by the government. The president answers directly to a minister, who, from 1979 to 1994 , was the Minister of Recreation, Hunting and Fishing. Since 1994, after the dissolution of that department, the QSSB has been the responsibility of the Minister of Municipal Affairs.

The budget for 1995 is 1.5 million dollars. Most of this involves salaries to the staff of 23 full time employees. Financial and human resources grew gradually from 500000 dollars and 20 employees in 1980 , to a high of 3 million dollars and 50 employees in 1990. Resources were reduced drastically in 1991 after a major reorganization of the board prompted by upcoming governmental budget cuts.

\section{Evolution of powers}

From 1979 to 1988, the QSSB concentrated its efforts on developing safety regulations for organized sports in col- 
laboration with amateur sports federations. It also developed regulations for professional boxing. It is important to specify that the QSSB has no regulatory power over other popular professional sports, such as ice hockey, baseball, or football because these are played in continent wide leagues. It would have been unrealistic to impose different rules on such professional teams when playing in Québec. As for boxing, however, because it involves discrete events it was possible to adopt more stringent regulations than those enforced elsewhere, even if that meant 'losing' some international fights because the promoters would not agree with Québec's rules.

From 1988 to 1991 , the QSSB was limited to working almost exclusively with organized sports federations, about $8 \%$ of all sports and recreation participants. For instance, while the Québec Alpine Skiing Federation (QASF) had 1000 members involved in competitive skiing, about 800000 Quebecers ski on a recreational basis and are, therefore, out of reach of QASF's safety regulations. Using one of the powers invested by the act, the QSSB moved in with regulations of its own in 1988 to improve the safety of all recreational skiers. The same situation was seen in ice hockey, where thousands of adult recreational players, outside the ranks of the Québec Ice Hockey Federation (QIHF) in so-called 'old-timers leagues', were not subject to safety regulations. Again, the QSSB stepped in and introduced regulations requiring the use of a helmet, a full face protector, and a throat protector for those players.

From 1991 to present, the QSSB has been concentrating on enforcing existing regulations and on developing voluntary safety standards for other outdoors activities, such as cross country skiing. Those standards, or parts of them, might eventually be included in future regulations. Examples of such standards are given below.

\section{Legislative and regulatory powers}

\section{SAFETY REGULATIONS IN ORGANIZED SPORTS}

In carrying out its functions, the board has the power to 'approve the safety regulations of a sports federation or unaffiliated sports body to ensure the safety of sports participants and spectators'. ${ }^{10}$ This involves developing and enforcing the standards shown in the table.

To date, the board has approved safety regulations for over 80 sports including, for example, baseball, basketball, volleyball, boxing, skiing, ice hockey, aquatic, racquet, and equestrian sports. It is estimated that 500000 children and adolescents between the age of 6 and 18 years old participate in leagues or tournaments now covered by those regulations.

\section{Development}

Regulations were developed jointly by the experts on the board and the respective sports federation. The develop-

\section{Standards developed or enforced by $Q S S B$}

For training facilities and equipment For training of participants

For participants in a sports event, contest, or exhibition For the training and responsibilities of persons required to play a part along with participants.

play a part along with participants.
For the training and the responsibilities of persons who enforce For the training and the

For organizing and holding a sports event, contest, or For organizing

For the places where a sports event, contest, or exhibition is For the
held

For the facilities and equipment used at a sports event, contest or exhibition

For safety services and equipment required at a sports event, contest, or exhibition

10. For the penalties for non-compliance with the regulation ment process was largely influenced by the willingness of the federations to cooperate, and by the resources at hand. Working with such non-profit organizations, often operated by volunteers, the QSSB mostly took a 'soft glove' approach. Even though one might consider safety as an issue about which no compromises could be tolerated, the QSSB recognized that under tight operating budgets, some of the smaller federations might need time to absorb the changes required by the act. For most federations, whatever their size, part of the task during the early years was to convince their leaders of the importance of adopting stricter safety standards, not only to protect the participants, but also to safeguard the integrity of their sport.

\section{Approval}

The approval process in the regulation calls for a proposal, developed jointly by the federation and board experts, to be adopted by the administrative board of the federation, who must then get the official approval of the administrative board of the QSSB. Approvals are usually given for five years, but modifications can be made earlier. The QSSB can make such modifications unilaterally (a rare event), but if the federation wants a change, it must obtain approval from the board. After five years, the regulation is reviewed, to ensure it is still up to date and, if needed, make changes. If no changes are required, it is automatically renewed.

\section{Enforcement}

According to the act, and in accordance with the federations' wish expressed during consultations, the enforcement of safety regulations are the responsibility of each sport's governing body. However, the board has the power to act alone if needed.

\section{Research}

The QSSB has a significant influence on safety regulations through the research it conducts or commissions. In ice hockey, for example, the QIHF changed its regulation in 1984 to ban body checking in all pee-wee divisions (12-13 years old). This followed a study showing that the risk of players in that age group suffering a fracture was 12 times greater in leagues that allowed players to body check. ${ }^{13}$ Other provinces followed the QIHF's decision, but 11 years later, the Canadian Ice Hockey Federation has still not changed its rule.

SAFETY REGULATIONS FOR RECREATIONAL ACTIVITIES In some instances, the QSSB can also intervene in 'leisure sport' activities practiced outside of organized competitive networks. It did so, for example, in the case of recreational alpine skiing. In 1992, there was an estimated 803000 alpine skiers in the province, $28 \%$ of whom were under 18 years of age. ${ }^{14}$ The same year, approximately 10000 of these young skiers received medical care for an injury. ${ }^{14}$ It was also reported that, in Québec, skiers under the age of 12 were twice as likely to suffer from a skiing injury as the rest of the skiing population. ${ }^{14}$

In light of the popularity of alpine skiing in Québec, the risks of injury involved, the lack of supervision under which it was practiced, and sparked by seven deaths in two seasons (1985 and 1986), the government mandated the QSSB to adopt and enforce new regulations to enhance the safety of this sport. These new regulations were directed at ski center operators and included requirements for signs, lighting for night skiing, qualifications for ski patrolers and 
monitors, first aid equipment, and the enforcement of a skier's code of conduct.

Although specific numbers for children and adolescents are not available, the rate of injuries/1000 ski days for all ages fell by $8 \cdot 2 \%$ between the 1989-90 and the 1991-2 seasons. ${ }^{15}$ Clearly, this reduction cannot be attributed to the regulation alone. Several other important possible preventive factors are not covered, notably, the equipment. A study is now underway to document more specifically the risks for skiers under 13 years of age.

\section{Standards for sports facilities}

One of the most efficient ways to improve sports safety is through the modification of the environment. ${ }^{16}$ In line with this passive protection approach, the QSSB developed a series of voluntary facilities standards, some of which are likely to eventually become regulations. Such standards have been adopted for ice rink arenas, ${ }^{17}$ cross country skiing trails, ${ }^{1819}$ and for European football, baseball, and softball fields. ${ }^{20}$ In all cases, the standards cover the design and maintenance of the facilities, and in some, they also cover the conditions for their safe operation. It is estimated that, for organized sports alone, 659000 children and adolescents use these facilities every year in Québec.

These three sets of voluntary standards have all been process evaluated, with encouraging results. ${ }^{21-23}$ Depending on the facility considered, between $75 \%$ and $90 \%$ of the owners/operators have consulted the standard; over $95 \%$ consider them 'useful' or 'very useful'; and between $36 \%$ and $58 \%$ have reportedly made changes to their facility within a year after receiving a copy of the standards. The impact of those changes on the rate of injuries is not yet known.

\section{Supporting municipalities in developing regula- tions}

As is true in other parts of the world, for many recreational activities, the legislative power to intervene rests in the hands of the municipalities. In Québec, this is the case for backyard swimming pools, for example. It has been suggested that regulating the fencing and other safety features around these pools would prevent drowning among young children. ${ }^{24-27}$ Legislating the safety features needed for the safe operation of private swimming pools is outside the jurisdiction of the QSSB. Nevertheless, to help municipalities that would like to adopt such regulations, but lack the expertise or resources to do so, the QSSB provided all municipalities with a prototype 'backyard swimming pool regulation' ${ }^{28}$ A survey in 1991 , one year after the prototype was distributed, showed that $17 \%$ of the municipalities voluntarily made some regulatory changes concerning these pools. ${ }^{29}$

\section{Some indicators of success}

In 1990, Québec was the province with the lowest rate of sport and recreational injuries in Canada: 67/1000 participants compared with $100 / 1000$ for the rest of the country. The province of British Columbia showed the highest rate $(176 / 1000){ }^{30-32}$ (Unfortunately, comparable statistics are not available for the period before the QSSB was created.)

Another measure of success is that from 1986 to 1992, the rate of hospitalization for sport and recreational injuries dropped by $26 \%$, while hospitalisations for injuries from other causes (motor vehicle, burns, intoxications, etc) only fell by $6 \% .{ }^{33}$ The denominator used for these rates was the total population, not only 'participants'. However, two province wide surveys, in 1987 and in 1992, showed that the rate of participation in sport and recreational activities did not change significantly over that period. ${ }^{14}{ }^{34}$ Changes in surgical procedures, however, now including 'day surgery', might explain part of this impressive reduction. The relatively 'minor' injuries suffered by many sport participants include many requiring surgical procedures that do not entail admission.

A third indicator of success is provided by a study of spinal cord injuries in youth ice hockey in Canada. Québec is the province where the rate of such severe injuries is the lowest in recent years. ${ }^{35}$ For instance, for 1987, Tator et al reported 26 cases in Ontario against only three in Québec. ${ }^{35}$ The difference in the number of players in these provinces is too small to explain this variation. The authors suggest that the stricter enforcement of the rules in Québec has resulted in a style of play more conducive to safety.

Although it is impossible to directly link these observations to the interventions of the QSSB, they strongly suggest trends in the right direction. Our biased evaluation is that, at the very least, the work of the QSSB over the last 15 years has contributed to the creation of a much safer climate for sports in the province.

\section{Towards the year 2000: partnership and intersec- toriality}

In 1991, the QSSB adopted a strategic plan aimed at the year 2000. The goal of the plan is 'to contribute to the social and economic balance sheet of sport and recreational activities in the province by reducing mortality, hospitalization and medical consultation rates by $15 \%$ before the year 2000' ${ }^{36}$ In 1992, this objective was incorporated in the health and welfare policy adopted by the province. ${ }^{37}$

To achieve the objective it set forth, the QSSB adopted the following four guiding principles:

1. Consider cost/benefits ratio when selecting an intervention strategy;

2. Consider the impact an intervention might have on the nature of the sport;

3. Choose interventions adapted to the problem at hand: either inform, convince, or contrive;

4. Encourage partnership.

Four general strategic intervention areas were identified: (1) training of coaches, teachers, first aid personnel, etc; (2) standards for facilities; (3) standards for personal equipment; and (4) attitudes and behaviors of participants.

The plan incorporated many of the conceptual advances made in the field of injury prevention in recent years. ${ }^{38-40}$ Foremost among those is the necessity to approach injury problems from an intersectorial point of view. This led the QSSB to sponsor the first summit on sport and recreation safety in 1993. It involved over 80 associations and governmental agencies from education, health, sports and recreation, both from the private and public sectors. The result was 13 three year action plans intended to improve sport and recreation safety in areas identified as priorities by a survey preceding the summit. One hundred and ten specific actions were identified, ranging from regulation modifications to social marketing campaigns. Most of the participating agencies committed themselves to carry out the actions falling within their responsibility. A flexible, easy to use follow up system has been established to track the progress made and to keep the momentum, so that the participating groups honor their commitment. ${ }^{41}$

\section{Interface with other governmental entities}

The summit has been a good occasion to strengthen ties with other governmental entities who share some respon- 
sibilites for providing safe environments for sports participants. The QSSB acts with those partners as a lobbyist, to put sports safety on their agenda. A good example is the development of safety seminars for physical education teachers developed in collaboration with the Education Department and delivered by school board personnel.

The QSSB also tries to work with other influential departments to raise the visibility of sports safety. One example is the inclusion of specific sports injury reduction objectives in the health and welfare policy adopted by the Health and Social Services Department in 1992.

Similarly the QSSB is often asked to contribute expertise into sports safety issues such as coroner's inquests, and governmental task forces on injury control.

Finally, as stated earlier, the QSSB has no legislative power over municipalities - owners of most sports and recreation facilities in the province. This means the board must work closely with associations representing municipal public work departments and recreation departments to develop voluntary safety programs.

\section{Conclusion}

The Quebec government created the QSSB in 1979 to address the many safety problems surrounding sports and recreational activities in the province and it is still the only agency of this kind in Canada. Over its 15 years of operation, the board has gradually incorporated the conceptual advances made in the field of injury control into its strategies of operation. The presence of a governmental entity clearly and solely responsible for the safety of sports and recreational participants carries two strong messages: (1) injuries resulting from sports and recreational activities are a significant public health problem, and (2) something can be done to prevent them from happening.

The presence of a body such as the QSSB also serves as a catalyst and a unifying force to channel and coordinate interventions from disparate groups, each holding part of the solution to this problem. It is hoped that this model of governmental intervention will inspire child injury prevention leaders in other countries to press their governments to adopt similar legislation.

They must, however, expect to meet some obstacles along the way. First, the scope of sports and recreation injuries in terms of incidence, medical costs, and long term disability is widely underestimated. Thus, the problem is often disregarded as insignificant and unworthy of political attention. Second, even if the scope of the problem is well known, there is a widespread belief that injuries are an inherent part of sports and recreational activities. Therefore, it is perceived that no amount of regulation will ever make a significant difference in the incidence and severity of such injuries. Third, one of the strong motivations drawing people to recreational activities, in particular to those practiced outdoors such as skiing, is the sense of liberty they provide. From that perspective, attempts at codifying these activities through regulations will not be well accepted. (Politicians might be sensitive to such objections if voiced by large numbers of voters.) Fourth, governing bodies can often be quite sensitive to outside interventions into the ruling of their sport, particularly if these come from government. Thus, any attempt to develop safety regulations for organized competitive sports should be made in collaboration with the sports federations. Moreover, there is a good chance that they will end up having to enforce the regulations themselves because it is not realistic for a sports safety board to do so in all cases.

On the other hand, there are several factors that could help to establish a model similar to the QSSB in other countries. Paradoxically, as sports related fatalities are relatively rare events, they often make the news. The one child who will die as a result of a skiing or football accident will draw much more attention from the media than the hundreds who die in car crashes. Although such media hype is usually just that, it is useful when it draws attention to the conditions having led to the unfortunate event. These are often the same conditions that lead to the nonfatal injuries suffered by thousands of children treated in emergency rooms. Once the pitfalls of the system have been publicly exposed, calls for new legislation, or for the creation of a new agency to prevent such events from happening again, have a better chance of being heard by politicians. For instance, there is little doubt that the coroner's inquests into such rare events, and the publicity surrounding them, were instrumental in the creation of the QSSB.

Although there are more data now available to demonstrate the scope and the severity of the sports injury problem, those data are a necessary but not sufficient condition to convince policy makers to address the problem. There are still too few well done studies demonstrating specifically the benefit of regulation on the reduction on sports injuries. Nevertheless, the studies that have been conducted provide a strong argument in favor of interventions that go beyond social marketing campaigns.

Finally, sports safety advocates have many natural allies: public health specialists, physical educators, physicians specialized in sports medicine, sports equipment manufacturers, standards development organizations, and parents. All can and should lend their support to persuade decision makers to provide safer conditions for children to play in. Sports should be fun and healthy for children; injuries are definitely not 'just part of the game'.

GUY RÉGNIER

Formerly research director of the $Q S S B$ CLAUDE GOULET

Research officer with the QSSB

Conseil d'Évaluation des Technologies de la Santé,

Tour de la Bourse, $42 e$ étage,

800 Place Victoria, BP 215,

Montréal,

Québec H4Z 1E3,

Canada

1 Kamphorst TJ, Roberts K Trends in sports: a multinational perspective. Utrecht, Netherlands: Giordano Bruno Culemborg, 1989.

2 Durand M. L'enfant et le sport. Paris: Presses Universitaires de France, 1987. 2 Durand M. L'enfant et le sport. Paris: Presses Universitaires de France, 1987. Children in sport. Champaign, IL: Human Kinetics Books, 1988: 17-24.

Children in sport. Champaign, IL: Human Kinetics Books, 1988: 17-24.
Valeriote TA, Hansen L. Youth sport in Canada. In: Smoll FL, Magill RA, Ash MJ, eds. Children in sport. Champaign IL: Human Kinetics Books, 1988: $25-30$.

5 Gallagher SS, Finison K, Goodenough S. The incidence of injuries among 87,000 Massachusetts' children and adolescents: results of the 1980-1981 statewide childhood injury prevention program surveillance system. $\mathrm{Am} \mathcal{f}$ Public Health 1984; 74: 1340-7.

6 Ellison LF, Mackenzie S. Aperçu des blessures sportives rapportées dans la base de données du programme des hôpitaux Canadiens pour la déclaration et la prévention des traumatismes. Maladies Chroniques du Canada 1993; 14: 107-16.

7 Backx FJG, Erich WBM, Kemper ABA, Verbeek AL. Sports injuries in school-aged children: an epidemiologic study. Am $\mathcal{F}$ Sports Med 1989; 17 : $234-40$

8 Kvist M, Kujala UM, Heinonen OJ, et al. Sports-related injuries in children. Int 7 Sports Med 1989; 10: 81-6.

9 Jacobsson B. Sports accidents among children and teenagers. A one-year study of incidence and severity in a Swedish rural municipality. Scanstudy of incidence and severity in a Swedish rural
dinavian fournal of Sports Science 1986; 8: 75-9.

10 Government of Québec. An act respecting safety in sports. Québec: Editeur Officiel du Québec, 1988.

11 Charron C. Prendre notre temps: livre vert sur le loisir au Québec. Québec: Haut-commissariat à la jeunesse, aux loisirs et aux sports, 1977.

12 Comité d'étude sur la violence au hockey amateur au Québec. Rapport Neron: la violence au hockey. Québec: Haut-commissariat à la jeunesse, aux loisirs et aux sports, 1977.

13 Régnier G, Boileau R, Marcotte G, et al. Effects of body-checking in the pee-wee (12 and 13 years old) division in the province of Quebec. In: Castaldi CR, Hoerner EF, eds. Safety in ice hockey, ASTM STP 1050. Philadelphia: American Society for Testing and Materials, 1989: 84-103. 
14 Régie de la sécurité dans les sports du Québec, ministère de la santé et des services sociaux du Québec. Sondage sur les blessures subies lors de la
pratique d'activités récréatives et sportives entre octobre 1992 et septembre pratique d'activités récréatives et sportives entre octobre 1992 et septembre

15 Goulet C, Régnier G. Effects of a governmental regulation regarding alpine skiing safety. Proceedings of the second world conference on injury control. Atlanta, 20-23 May 1993.

16 Janda DH, Wojtys EM, Hankin FM et al. Softball sliding injuries: a prospective study comparing standard and modified bases. $\mathcal{F} A M A 1988$; 259: $1848-50$.

17 Régie de la sécurité dans les sports du Québec, Association des arénas du Québec. Guide de sécurité et de prévention dans les arénas. Trois-Rivières: Gouvernement du Québec, 1992.

18 Régie de la sécurité dans les sports du Québec. Ski de fond: normes d'aménagement et d'entretien des sentiers. Trois-Rivières: Gouvernement du Québec, 1991.

19 Régie de la sécurité dans les sports du Québec. Ski de fond: normes de signalisation des sentiers. Trois-Rivières: Gouvernement de Québec, 1992.

20 Régie de la sécurité dans les sports du Québec. Guide d'aménagement et d'entretien des terrains extérieurs: baseball, soccer, softball. Trois-Rivières: Gouvernement du Québec, 1992.

21 Service de la recherche et de la planification, Régie de la sécurité dans les sports du Québec. Guide de sécurité et de prévention dans les arénas. Evaluation de la réception et de l'impact. Trois-Rivières: Régie de la sécurité dans les sports du Québec, 1993.

22 Service de la recherche et de la planification, Régie de la sécurité dans les sports du Québec. Evaluation de la réception et de l'impact des normes de signalisation et des normes d'aménagement et d'entretien des sentiers de ski de fond. Trois-Rivières: Régie de la sécurité dans les sports du Québec, 1993.

23 Service de la recherche et de la planification, Régie de la sécurité dans les sports du Québec. Evaluation de la réception et de l'impact du guide d'aménagement et d'entretien des terrains extérieurs. Trois-Rivières: Régie d'aménagement et d'entretien des terrains extérieurs.

24 Barry W, Little TM, Sibert JR. Drownings in private swimming pools: an avoidable cause of death. $B M \mathcal{M}$ 1982; 285: 542-3.

25 Milner N, Pearn J, Guard R. Will fenced pools save lives? A 10-year study from Mulgrave Shire, Queensland. Med $\mathcal{F}$ Aust 1980; ii: 510-1.

26 Elkington J, Carey V, Albany P, et al. Swimming pool fencing legislation:
Australia's experience (abstract). Proceedings of the second world injury conference on injury control. Atlanta, 20-23 May 1993.

27 The Canadian Red Cross Society. The national drowning report. Ottawa: The Canadian Red Cross Society, 1993.

28 Régie de la sécurité dans les sports du Québec. Règlement type concernant les piscines résidentielles. Trois-Rivières: Régie de la sécurité dans les sports du Québec, 1989.

29 Service de la recherche et de la planification, Régie de la sécurité dans les sports du Québec. Evaluation de l'impact du règlement type sur les piscines résidentielles auprès des municipalités du Québec. Trois-Rivières: Régie de la sécurité dans les sports du Québec, 1991.

30 Statistique Canada. Accidents au Canada. Enquête sociale générale. Ottawa: Ministère des Approvisionnements et Services, 1991.

31 Enquête Condition Physique Canada. Condition physique et mode de vie au Canada. Ottawa: Enquête Condition Physique Canada, 1988.

32 Santé et Bien-être social Canada. Rapport technique: enquête promotion santé Canada. Ottawa: Ministère des Approvisionnements et Services, 1988.

33 Régnier G. Portrait des traumatismes d'origine récréative et sportive au Québec de 1986 a 1992 : mortalité, hospitalisations, consultations médicales et limitations d'activitié. Trois-Rivières: Régie de la sécurité dans les sports du Québec, 1994.

34 Gollin G. Sondage sur les blessures subies par les québécois lors de la pratique d'activités physiques et sportives. Montréal: Créatec,+ 1988

35 Tator CH, Edmonds VE, Lapczak L, et al. Spinal injuries in ice hockey players: 1966 to 1987. Can f Surg 1991; 34: 63-9.

36 Régie de la sécurité dans les sports du Québec. Rapport annuel 1991. Québec: Gouvernement du Québec, 1992.

37 Ministre de la santé et des services sociaux. La politique de la santé et du bien-être. Québec: Ministère de la Santé et des Services sociaux, 1992.

38 Waller JA. Injury: Conceptual shifts and preventive implications. Annu Rev Public Health 1987; 8: 21-49.

39 Baker SP. Injury science comes of age. $7 A M A$ 1989; 262: 2284-5.

40 Haddon W, Baker SP. Injury control. In: Clark C, MacMahon B, eds. Preventive and Community Medicine. Boston: Little, Brown, 1991: 109-40.

41 Régie de la sécurité dans les sports du Québec. Rapport annuel 1993. Québec: Gouvernement de Québec, 1994. 